\title{
PERNIKAHAN ANAK DI INDIA
}

\author{
Indah Fatmawati ${ }^{1}$
}

\begin{abstract}
Abstrak:
Ketimpangan gender yang terjadi di seluruh dunia salah satunya adalah karena kesalah pahaman dalam memaknai gender itu sendiri. Di India sendiri terdapat United Nations Childern's Fund yang bertugas menangani kasus pernikahan anak di India. Pernikahan anak ini menjadi sorotan di Komunitas Internasional dan menjadi isu penting karena adanya kasus pernikahan anak ini menghambat Sustainable Development Goals yang ditetapkan pada tahun 2015 oleh Majelis Umum PBB. Masih banyak anak-anak perempuan yang berpendidikan lebih rendah dibandingkan dengan anak laki-laki. Dari masalah tersebut, maka penulis akan membahas mengenai bagaimana pemahaman masyarakat India terhadap pernikahan anak yang terjadi di India. Penelitian ini adalah jenis penelitian kepustakaan dengan menggunakan kajian pustaka yang mengambil sumber primer dan sekunder dari buku-buku, artikel, dan tema-tema yang disampaikan oleh para peneliti dalam bidang gender. Dari penelitian tersebut dapat disimpulkan bahwa praktik pernikahan anak di india telah dilakukan selama berabad-abad dan membuat UNICEF yang merupakan organisasi Internasional yang bergerak untuk menegakkan hak anak dan perempuan ikut terlibat melalui berbagai inisiatif program kerja untuk menangani kasus pernikahan anak dibawah umur di India. Pernikahan pada anak yang terjadi di India tidak lepas dari adanya bias gender terutama karena rendahnya tingkat pendidikan anak perempuan yang terjadi di India.
\end{abstract}

Kata Kunci: anak perempuan di India, pernikahan anak.

\section{PENDAHULUAN}

Dalam setiap masyarakat, kaum laki-laki dan perempuan memiliki peran yang berbeda. Terdapat perbedaan pekerjaan yang mereka lakukan dalam komunitas dan status maupun kekuasaan mereka di dalam masyarakat boleh jadi berbeda pula. Perbedaan jalan perkembangan peran gender dalam masyarakat disebabkan oleh berbagai macam faktor, mulai dari lingkungan alam, hingga cerita dan mitos yang digunakan untuk memecahkan teka-teki perbedaan jenis kelamin, mengapa perbedaan itu terjadi dan bagaimana dua orang yang berlainan jenis kelamin dapat berhubungan baik satu dengan yang lainnya dan dengan sumber daya alam sekitarnya. ${ }^{2}$ Terbentuknya perbedaan-perbedaan gender dikarenakan oleh banyak hal, di antaranya dibentuk, disosialisasikan, diperkuat, bahkan dikonstruksi secara sosial atau kultural, melalui ajaran keagamaan maupun negara. Perbedaan itu akhirnya dianggap sebagai ketentuan Tuhan, seolah-olah bersifat biologis yang tidak bisa dirubah. ${ }^{3}$

Perihal perbedaan gender tidak hanya terjadi di Indonesia namun diseluruh belahan dunia, termasuk di India. Di Indonesia pergerakan tentang perjuangan akan

\footnotetext{
${ }^{1}$ Pascasarjana Institut Agama Islam Negeri Ponorogo.

${ }^{2}$ Edi Wibowo, "Peran Ganda Perempuan Dan Kestaraan Gender," Muwazah 3 No. 1 (2011).

${ }^{3}$ Achmad Irwan Hamzani, "Pembagian Peran Suami Isteri Dalam Keluarga Islam Indonesia (Analisis Gender Terhadap Inpres No. 1 Tahun 1991 Tentang Kompilasi Hukum Islam)," Sosekhum Universitas Pancasakti Tegal Vol. 6 No. 9 (2010): 7.
} 
hak-hak perempuan timbul karena adanya kesadaran pergaulan, dan arus informasi yang membuat perempuan Indonesia semakin kritis dengan apa yang menimpanya. ${ }^{4}$ Sementara dalam kisahnya perbedaan gender di India ini mulai terjadi bahkan ketika anak itu lahir, mulai dari ketidakadilan gender dalam Pendidikan, dimana tingkat Pendidikan bagi anak perempuan masih sangat rendah jika dibandingkan dengan laki-laki, rendahnya tingkat Pendidikan tersebut berpengaruh pada maraknya pernikahan anak di India. Pola pikir tersebut bisa saja dipengaruhi oleh pemahaman tentang maskulinitas laki-laki dan feminitas pada perempuan. ${ }^{5}$

\section{PEMBAHASAN}

\section{Pehaman tentang Gender}

Gender diartikan sebagai “interpretasi mental dan kultural terhadap perbedaan kelamin yakni laki-laki dan perempuan. Gender dipergunakan untuk menunjukkan pembagian kerja yang dianggap tepat bagi laki-laki dan perempuan. Untuk memahami konsep gender, seharusnya dibedakan kata gender dengan kata sex (jenis kelamin). Pengertian jenis kelamin adalah pensifatan atau pembagian dua jenis kelamin manusia yang ditentukan secara biologis, misalnya ada manusia dengan jenis kelamin laki-laki dengan berbagai macam organ tubuhnya, dan ada jenis kelamin perempuan. Perbedaan biologis (jenis kelamin) adalah kodrat Tuhan yang secara permanen berbeda. ${ }^{6}$

Kesetaraan (equality) diartikan sebagai suatu keadaan menjadi setara atau sama dalam jumlah, ukuran, nilai, kualitas atau tingkatan. Secara konseptual, keadilan (equity) suatu keadaan yang menunjukkan kualitas untuk menjadi keterbukaan dan kesamaan kesempatan atau suatu keadaan untuk menjadi patut, semestinya dan adil dalam hal distribusi sumber daya, keuntungaan dan pertanggungjawaban. Untuk mengukur keadilan, ada beberapa indikator antara lain akses dan kontrol terhadap kebutuhan-kebutuhan praktis dan strategis bagi setiap anggota masyarakat baik laki-laki, perempuan, tua, muda; partisipasi yang sama dan sebanding dalam berbagai aktivitas pembangunan serta pembagian yang sama dan sebanding dalam kekuasaan serta wewenang di dalam rumahtangga dan masyarakat serta manfaat.

Sementara bentuk ketidakadilan gender dapat berupa marginalisasi, subordinasi, stereotipe (pelabelan) negatif, kekerasan, beban berlebihan (double

\footnotetext{
${ }^{4}$ Syahrul Amar, "Perjuangan Gender Dalam Kajian Sejarah Wanita Indonesia Pada Abab XIX," Fajar Historia Vol. 1 No. (2017).

${ }^{5}$ Alfian Rokhmansyah, Pengantar Gender Dan Feminisme (Yogyakarta: Garudhawaca, 2016), 8.

${ }^{6}$ Hamzani, "Pembagian Peran Suami Isteri Dalam Keluarga Islam Indonesia (Analisis Gender Terhadap Inpres No. 1 Tahun 1991 Tentang Kompilasi Hukum Islam)."
} 
burden). ${ }^{7}$ Terbentuknya perbedaan-perbedaan gender dikarenakan oleh banyak hal, di antaranya dibentuk, disosialisasikan, diperkuat, bahkan dikonstruksi secara sosial atau kultural, melalui ajaran keagamaan maupun negara. Perbedaan itu akhirnya dianggap sebagai ketentuan Tuhan, seolah-olah bersifat biologis yang tidak bisa dirubah. Perbedaan jenis kelamin yang selanjutnya melahirkan peran gender (gender role) sesungguhnya tidak menimbulkan masalah sehingga tidak perlu digugat. Misalnya secara biologis kaum perempuan dengan organ reproduksnya bisa hamil, melahirkan dan menyusui yang menjadi masalah dan perlu digugat oleh mereka yang menggunakan "analisis gender" adalah struktur "ketidakadilan" yang ditimbulkan oleh "peran gender" sehingga perempuan dimarjinalkan dalam sektor peran publik. Gender selanjutnya dipergunakan sebagai alat analisis oleh kaum feminis pada ketidakadilan struktural dan sistem yang disebabkan oleh gender. ${ }^{8}$

Di India anak berada dalam posisi yang rentan karena usianya dan jenis kelaminnya. Diskriminasi terhadapnya dimulai sejak konsepsi dan kelahiran dan berlanjut sampai masa kanak-kanak, remaja dan dewasa. Alasan bias gender ini adalah sosio-legal dan budaya. Masyarakat India menderita son-syndrome. Seorang anak laki-laki diharuskan untuk membatasi keluarga agar dapat mengurus bisnis dan properti keluarga dan untuk memberikan keamanan ekonomi dan emosional kepada orang tua di usia tua mereka. Selain itu, ia sendiri dapat melakukan ritual terakhir dan upacara penguburan sang ayah dan "membebaskannya dari neraka". 9 Di samping itu gadis bertanggungjawab karena kesuciannya harus dilindungi dan juga menjadi beban karena mahar adat. Sejak menikah seorang gadis meninggalkan rumah orang tuanya untuk tinggal bersama suaminya dan mertuanya di sebagian besar masyarakat India membelanjakan uang untuk pendidikan dan kesehatannya dipandang sebagai investasi yang sia-sia dan seperti halnya menyiram kebun orang lain. Meskipun waktu secara bertahap mengubah diskriminasi dan bias pada kisahkisah ini masih sangat jelas dan tetap ada. ${ }^{10}$

Sementara pada prinsipnya antara laki-laki dan perempuan memiliki hak yang sama, yakni hak asasi sebagai manusia yang melekat pada masing-masing individu. Gagasan mengenai HAM dibangun atas dasar prinsip kesetaraan. Prinsip ini menekankan bahwa manusia berkedudukan setara harkat dan martabatnya. ${ }^{11}$

${ }^{7}$ Khusnul Khotimah, "Diskriminasi Gender Terhadap Perempuan Dalam Sektor Pekerjaan," Studi Gender Dan Anak Yin Yang Pusat Studi Gender STAIN Purwokerto Vol. 14 No. 1 (2009): 163-165.

${ }^{8}$ Hamzani, “Pembagian Peran Suami Isteri Dalam Keluarga Islam Indonesia (Analisis Gender Terhadap Inpres No. 1 Tahun 1991 Tentang Kompilasi Hukum Islam)."

9 Murlidhar C. Bandhare, The World of Gender Justice (New Delhi: Har-and Publications PVT LTD, 1999), 230-231.

${ }^{10}$ Bandhare, The World of Gender Justice.

${ }^{11}$ Andrey Sujatmoko, Hukum HAM Dan Hukum Humaniter (Jakarta: Raja Grafindo Persada, 2015), 11. 
Sehingga seharusnya perbedaan antara laki-laki dan perempuan yang banyak terjadi itu dikesampingkan.

Berbagai perjanjian internasional, instrumen hak asasi manusia dan program kebijakan nasional telah dicanangkan di India, seperti Deklarasi Gencva tentang hak-hak anak 1924, Deklarasi Universal Hak Asasi Manusia 1948, Konvensi PBB tentang hak-hak Anak 1989, dan banyak deklarasi internasional lainya dan konferensi dunia telah menekankan perlunya perlindungan khusus anak. Konstitusi India, "paedeatric" di mana ketentuan tersebut dibuat untuk kesejahteraan anak-anak sesuai dengan hukum telah banyak dibuat. Pasal 23 melarang perdagangan manusia dan tenaga kerja paksa, pasal 24 melarang mempekerjakan anak-anak di bawah usia 14 tahun untuk bekerja apapun di pabrik atau tambang atau pekerjaan berbahaya lainnya, Pasal 39 huruf (e) mengarahkan negara untuk melindungi anak-anak sehingga usia pekerja anak tidak disalah gunakan dan mereka tidak dituntut secara ekonomi untuk mengambil pekerjaan yang tidak terkait dengan usia dan kekuatan mereka, sementara berdasarkan pasal 39 huruf (f) negara berkewajiban untuk memastikan bahwa anak-anak diberikan kesempatan dan fasilitas untuk berkembang secara sehat dan dalam kondisi kebebasan dan martabat dan bahwa masa kanak-kanak dan remaja dilindungi dari eksploitasi dan terhadap pengabaian moral dan materi, Pasal 45 memberikan pendidikan gratis dan wajib untuk semua anak hingga usia 14 tahun. Terlepas dari ketentuan konstitusi ini, ada berbagai kebijakan dan program nasional untuk kesejahteraan anak-anak. Kebijakan Nasional Anak-anak tahun 1974 menetapkan " Kebijakan Nasional Anak-anak tahun 1974 akan menjadi kebijakan negara untuk memberikan layanan yang memadai untuk anak-anak, baik sebelum dan sesudah kelahiran dan melalui pertumbuhan untuk memastikan fisik, mental dan sosial mereka sepenuhnya". Berdasarkan semua perkembangan ini, berbagai rencana aksi dan skema telah diadopsi dengan memberikan langkah-langkah untuk memberikan kesejahteraan anak-anak. ${ }^{12}$

Anak adalah bagian yang tak terpisahkan dari keberlangsungan hidup manusia dan keberlangsungan suatu bangsa dan negara. Dan sebagai bagian dari keluarga, masyarakat, atau bahkan negara, anak-anak memiliki hak-hak yang perlu dilindungi agar mereka dapat tumbuh dan berkembang sebagaimana layaknya orang dewasa. Anak adalah masa depan bangsa dan generasi penerus cita-cita bangsa, sehingga setiap anak berhak atas kelangsungan hidup, tumbuh, dan berkembang, berpartisipasi serta berhak atas perlindungan dari tindak kekerasan dan diskriminasi serta hak sipil dan kebebasan. ${ }^{13}$ Dari penjelasan tersebut maka sudah seharusnya anak dilindungi dari ketidakadilan dan diskriminasi.

\footnotetext{
${ }^{12}$ Bandhare, The World of Gender Justice, 230.

${ }^{13}$ Badilag MA RI, "Jalan Panjang Kewenangan Mengawal Hak-Hak Anak”, Majalah Peradilan Agama Edisi 9," n.d., 4.
} 


\section{Pernikahan anak di India}

Perkawinan atau pernikahan sangat penting dalam kehidupan manusia karena dengan perkawinan yang sah mengakibatkan pergaulan antara laki-laki dan perempuan menjadi terhormat sesuai dengan kedudukan manusia sebagai mahluk yang terhormat. Pergaulan hidup berumah tangga dibina dalam suasana damai, tentram dan kasih sayang antara suami dan istri. Sementara anak hasil keturunan perkawinan sah yang menghiasi kehidupan berumah tangga merupakan perhiasan kehidupan berumah tangga sekaligus merupakan kelangsungan hidup manusia secara bersih dan terhormat. ${ }^{14}$

Dalam konteks anak perempuan, pemikiran serius perlu diberikan pada masalah pernikahan anak. Pernikahan anak memiliki efek yang sangat berbahaya pada pikiran, tubuh, dan kesehatan gadis itu. Sebelum KUHP India, 1860, tidak ada ketentuan yang melarang hidup bersama antara pria dan istrinya berapapun usianya. Para Komisaris Hukum yang menyusun Kode pada tahun 1846 memperdebatkan gagasan untuk menghukum pernikahan di bawah usia tertentu. Kode 1860 menetapkan pada usia 10 tahun dan suami yang melakukan pernikahan dengan istrinya yang berusia di bawah 10 tahun harus dinyatakan bersalah atas pemerkosaan dan hukuman yang ditentukan dapat diperpanjang berjalan seumur hidup. Selama 30 tahun, peraturan ini terus berjalan sampai keputusan Pengadilan Tinggi Calcutta di Ratu Empress v Hurree Mohan Muthee (di mana kematian seorang gadis sebelas tahun yang disebabkan oleh perdarahan dalam perjalanan hidup bersama) menyebabkan pensosialisasian dari RUU yang menaikkan usia dari 10 tahun menjadi 12 tahun. Pada tahun 1924 Dr. Hari Singh Gour memperkenalkan daftar sementara pemerkosaan pada Pasal 375 Kode India, anoma dengan usia 15 tahun di Amerika Serikat.

Pendapat tentang RUU yang dibagikan dengan tajam itu masih bisa ditembus. Namun, opini publik sangat kuat tentang perlunya untuk memulai RUU tersebut. Pada tahun 1925, usia untuk penyempurnaan legal dinaikkan menjadi 13 tahun. Undang-undang Penahanan Pernikahan 1929 menaikkan pernikahan masingmasing menjadi hingga 18 tahun. 14 tahun untuk anak laki-laki dan perempuan. Pada tahun 1949 usia adalah 15 tahun untuk anak perempuan dan dengan amandemen pada tahun 1978 usia pernikahan telah menjadi 18 tahun untuk anak perempuan dan 21 tahun untuk anak laki-laki. Perkawinan yang bertentangan dengan kode ini dapat dipaksakan dengan denda dan/atau hukuman penjara. Namun demikian di Rajasthan saja, ribuan dokter dengan senang hati menikah pada hari "Akha Teej" setiap tahun. Pernikahan anak dilaporkan dari bagian lain negara itu juga. Kadang-kadang pengantin perempuan begitu muda sehingga mereka harus digendong oleh ibu mereka. Dewan Perempuan telah membuat RUU yang

${ }^{14}$ Tri Lisiani Prihatinah, “Tinjauan Filosofis Undang-Undang Nomor 1 Tahun 1974," Dinamika Hukum Vol. 8 No. 2 (2008): 167.. 
berusaha menjadikannya sebagai kesalahan bagi semua pernikahan untuk dicatat dan didaftarkan. Langkah itu, sebagai pembelaan dan perlindungan hukum. ${ }^{15}$

Bagian 375 dari KUHP "hubungan seksual oleh seorang pria yang istrinya sendiri tidak berusia 15 tahun, bukan pemerkosaan" dengan demikian, jika seorang istri melakukan hubungan seksual dengan seorang pria, dia setuju atau tidak, suami tidak bisa bersalah, jika isteri di bawah 15 tahun maka suaminya akan bersalah tetapi di sini juga menimbulkan kesalahan pada istri di bawah 12 tahun, tetapi jika istri tidak di bawah 12 atau di atas tetapi lebih rendah 15 tahun (lebih rendah 15 tahun karena tidak ada pelanggaran sama sekali) maka ia menggunakan dasar sebagai tindakan kriminal dan hukuman yang lebih ringan. Ini adalah anakronistis (penempatan kejadian pada waktu yang salah) bahwa tumpukan tahun 1978 menaikkan usia untuk menikah menjadi 18 tahun untuk anak perempuan, untuk romain konsumsi pernikahan pada usia 15 tahun di bawah KUHP Ini. Perlu dipikirkan serius jika praktik perkawinan anak dengan efek buruknya yang bersamaan pada anak perempuan itu, harus dikontrol. ${ }^{16}$

Penikahan pada anak di India bisa juga termasuk dalam salah satu bentuk kekerasan berbasis gender, seperti pemerkosaan terhadap perempuan, termasuk pemerkosaan dalam perkawinan. ${ }^{17}$ Kekerasan fisik dalam rumahtangga, kekerasan dalam bentuk pelacuran, kekerasan dalam bentuk pornografi, pemaksaan dalam sterilisasi dalam keluarga berencana, kekerasan terselubung yakni dalam bentuk memegang atau menyentuh bagian tertentu dari tubuh perempuan dengan berbagai cara dan kesempatan tanpa kerelaan yang bersangkutan, pelecehan seksual. ${ }^{18}$

Pernikahan pada anak yang terjadi di India tidak lepas dari adanya bias gender yang lain, yang terjadi di India, dampak dari bentuk ketimpangan gender lainya, diantaranya yakni ketimpangan dalam bidang pendidikan dan ketenaga kerjaan. Beberapa rencana aksi, skema dan program telah diadopsi untuk meningkatkan keadaan anak perempuan. Sebagai contoh di bawah skema di Haryana, yang dikenal sebagai "Apni Rot Apmi Dhan" (sumber putri seseorang yang berharga) negara berjanji untuk menyediakan makanan dan pengasuhan anak perempuan. Banyak negara bagian lain memiliki skema serupa. SAARC telah mendeklarasikan 1991-2000 sebagai "Dekade Anak Perempuan" dan rencana aksi nasional untuk anak perempuan pada tahun 1991-2000 telah ditarik oleh pemerintah yang mengakui hak-hak anak perempuan untuk kesempatan yang sama, untuk menjadi bebas dari kelaparan, buta huruf, kebodohan dan eksploitasi. Namun demikian, SAARC belum memiliki komitmen dan kemauan politik untuk bertindak

${ }^{15}$ Bandhare, The World of Gender Justice, 234.

${ }^{16}$ Bandhare, 235.

${ }^{17}$ Anita Rahmawati, "Harmoni Dalam Keluarga Perempuan Karir," Palastren STAIN Kudus Jawa Tengah Vol. 8 No. 1 (2015): 12. 
ke arah itu dengan menyebarkan kesadaran dan menciptakan kondisi di mana anak perempuan dapat hidup bermartabat dan diperlakukan sebagai aset daripada sebagai beban. ${ }^{19}$ India menjadi salah satu negara yang terus melakukan upaya untuk menegakkan keadilan gender, dengan membuat aturan-aturan yang relefan dan melindungi hak-hak perempuan.

Berdasarkan Pasal 45 Konstitusi India memberikan pendidikan gratis dan wajib kepada anak hingga usia 14 tahun untuk anak laki-laki maupun perempuan. Namun tingkat melek huruf sangat rendah, dalam hal ini anak perempuan, tingkat pendaftaran masih rendah dibandingkan dengan anak laki-laki. Sikap social-budaya juga berkontribusi pada tingkat melek huruf yang lebih rendah dikalangan anak perempuan. Keyakinan bahwa tugas perempuan adalah melahirkan anak dan menjaga rumah masih melekat. Semakin tinggi Pendidikan seorang gadis, semakin sulit untuk menemukan pasangan yang cocok untuknya. ${ }^{20}$

Secara psikologis, tidak ada satupun teori yang menyatakan bahwa laki-laki lebih cerdas dibandingkan kaum perempuan. Tidak ada satupun data ilmiah yang menyatakan bahwa perempuan lebih bodoh daripada laki-laki. Hasil intelegensi menunjukkan bahwa perempuan mendapatakan skor yang relatif sama dengan para laki-laki. Sementara ketidakadilan gender biasanya terjadi pada Pendidikan formal. Ketidakadilan gender bisa dirubah menjadi keadilan gender sesuai dengan normatifnya kedua jenis kelamin sebagai sumber daya manusia. Keduanya harus dipandang sebagai asset sumber daya pembangunan oleh karena itu kebutuhan gender praktis dan strategis keduanya harus diperhatikan. ${ }^{21}$

Di India sendiri terdapat United Nations Childern's Fund dalam penanganan kasus pernikahan anak di India. Dimana pernikahan di bawah umur tersebut tentunya banyak berdampak negative, terlebih untuk anak perempuan. Pernikahan anak di bawah umur ini telah menjadi sorotan di komunitas internasional dan menjadi isu penting karena adanya kasus pernikahan anak di bawah umur menjadi penghambat tercapainya Sustainable Development Goals yang ditetapkan pada tahun 2015 oleh Majelis Umum PBB. Praktik pernikahan anak di India telah dilakukan selama berabad-abad dan membuat UNICEF yang merupakan sebuah organisasi internasional yang bergerak untuk menegakkan hak anak dan perempuan ikut teribat melalui berbagai inisiatif program kerja untuk menangani kasus pernikahan anak dibawah umur di India. ${ }^{22}$

Jika dibandingkan dengan Indonesia. Di Indonesia diatur pula ketentuan tentang pernikahan anak, dimana Undang-Undang secara tegas mengatakan bahwa

\footnotetext{
${ }^{19}$ Bandhare, The World of Gender Justice, 236.

${ }^{20}$ Bandhare, 231.

${ }^{21}$ Siti Rokhimah, "Patriarkhisme Dan Ketidakadilan Gender," Muwazah Vol. 6 No. 1 (2014).

${ }^{22}$ Kurniasari, "Peran United Nations Chilren's Fund (UNICEF) Terhadap Penanganan Kasus Pernikahan Anak Di bawah Umur Di India Tahun 2013-2017" (Universitas Pembangunan Nasional Veteran Yogyakarta, 2018), 1.
} 
anak yang belum memenuhi batas usia pernikahan hanya bisa melakukan pernikahan setelah adanya izin dari Pengadilan. Hal tersebut tentunya diatur untuk melindungi hak-hak anak terutama anak perempuan yang lebih sering menjadi korban dalam urusan rumah tangga terlebih lagi jika si suami tidak bertanggungjawab, maka perempuan akan memiliki beban ganda untuk memelihara anaknya serta mencukupi kebutuhan hidupnya sendiri, belum lagi beban psikis yang harus ia rasakan. Sebelumnya tentang pernikah anak sudah diatur dalam Undang-Undang Nomor 01 tahun 1974 tentang Perkawinan. ${ }^{23}$ Dijelaskan bahwa calon suami istri yang belum mencapai usia 19 dan 16 tahun yang ingin melangsungkan perkawinan, orang tua yang bersangkutan harus mengajukan permohonan dispensasi kawin kepada Pengadilan Agama/Mahkamah Syar'iyah. Undang-Undang Nomor 01 tahun 1974 dirubah menjadi Undang-Undang Nomor 16 tahun 2019 tentang perubahan atas Undang-Undang Nomor 01 tahun 1974 tentang Perkawinan pada Pasal 7, dimana batas usia menikah adalah 19 tahun untuk pria dan wanita. ${ }^{24}$

Sementara dalam Undang-Undang nomor 23 Tahun 2002 tentang Perlindugan Anak menjelaskan bahwa perkawinan yang dilakukan oleh seseorang yang berusia kurang dari 18 tahun disebut sebagai perkawinan anak dan orang tua wajib mencegah terjadinya perkawinan anak. Begitu juga pendapat Bogue dalam Dini Risya 2011 yang mengelompokkan usia perkawinan pertama kurang dari 18 tahun sebagai child marriage. ${ }^{25}$ Puji hastuty menyatakan bahwa berdasarkan kovensi hak anak, batas awal dewasa anak adalah usia 18 tahun. Dalam Undang-Undang perlindungan anak juga menyebutkan bahwa orang tua wajib mencegah terjadinya perkawinan anak (usia muda). Perkawinan di usia muda merupakan suatu pelanggaran terhadap hak anak karena anak akan kehilangan hak anak untuk bermain bersama teman sebayanya. ${ }^{26}$

Seiring berjalanya waktu para perempuan di Indonesia mulai meyadari akan pentingnya Pendidikan, sehingga banyak perempuan yang sekarang melanjutkan Pendidikan yang lebih tinggi, tidak sedikit pula para perempuan yang menduduki kursi penting dalam struktur pemerintahan di Indonesia, misalnya menteri kelauatan Susi Pujiastuti, Menteri keuangan Sri Mulyani dan masih banyak perempuan lain yang tentunya berperan penting dalam pemerintahan di Indonesia. Sehingga pola pikir perempuan Indonesia sudah semakin maju, perempuan diperbolehkan berpendidikan tinggi, dan tidak melulu hanya berkutat ada wilayah

\footnotetext{
24 “Undang-Undang Nomor 16 Tahun 2019 Tentang Perubahan Atas Undang-Undang Nomor 01 Tahun 1974 Tetang Perkawinan," n.d.

${ }^{25}$ Mariyatul Qibtiyah, "Faktor Yang Mempengaruhi Perkawinan Muda Perempuan," Biometrika Dan Kependudukan Vol. 3 No. 1 (2014): 55.

${ }^{26}$ Qibtiyah, 56.
} 
domestik karena keterbatasan pengetahuan dan ketrampilan yang dimiliki, namun bisa eksis di wilayah publik. Timbulnya kesadaran tersebut tentunya dipengaruhi oleh adanya semangat yang timbul untuk merentaskan keterbelakangan pada kaum perempuan. Kondisi sosial dan budaya yang ada membuat perempuan Indonesia di masa lalu terbelengggu.

Pendidikan adalah proses penyiapan generasi muda agar dapat menjalankan kehidupan dan memenuhi tujuan hidupnya secara efektif danefisien. ${ }^{27}$ Indonesia secara tegas menyatakan bahwa tidak ada perbedaan dan pembedaan antara lakilaki dan perempuan, sebagaimana yang tertulis dalam UUD 1945 Pasal 27 dan 31 UU RI nomor 2 tahun 1989 dan UU RI nomor 20 tahun 2003 tentang Sistem Pendidikan Nasional juga menjamin hak dan kesempatan yang sama bagi semua warga untuk andil dalam bidang pendidikan. ${ }^{28}$

Perlindungan hukum terhadap anak merupakan upaya perlindungan berbagai kebebasan hak asasi anak (fundamental rights and freedom of children), serta berbagai kepentingan yang berhubungan dengan kesejahteraan anak. Perlindungan hukum bagi anak mencakup lingkup yang luas. Dalam perspektif kenegaraan, negara melindungi warga negaranya termasuk didalamnya terhadap anak dapat di temukan dalam pembukaan UndangUndang Dasar 1945 yang tercermin pada alinea Ke-IV, didalam penjabarannya bab XA tentang Hak Asasi Manusia, khususnya untuk perlindungan terhadap anak, Pasal 28B ayat (2) UUD1945 dinyatakan bahwa setiap anak berhak atas kelangsungan hidup, tumbuh dan berkembang, serta berhak atas perlindungan dari kekerasan dan diskriminasi. ${ }^{29}$

\section{KESIMPULAN}

Bias gender terbentuk karena banyak hal, di antaranya dibentuk, disosialisasikan, diperkuat, bahkan dikonstruksi secara sosial atau kultural, melalui ajaran keagamaan maupun negara. Perbedaan itu akhirnya dianggap sebagai ketentuan Tuhan, seolah-olah bersifat biologis yang tidak bisa dirubah. Praktik pernikahan anak di India telah dilakukan selama berabad-abad dan membuat UNICEF yang merupakan sebuah organisasi internasional yang bergerak untuk menegakkan hak anak dan perempuan ikut terlibat melalui berbagai inisiatif program kerja untuk menangani kasus pernikahan anak dibawah umur di India. Telah diatur pula Undang-Undang yang mengatur hal tersebut.

Di India sendiri terdapat United Nations Childern's Fund dalam penanganan kasus pernikahan anak di India. Dimana pernikahan di bawah umur tersebut

\footnotetext{
${ }^{27}$ Evi Muafiah, “Realitas Segregasi Gender Di Pesantren," in Proceedings of Annual Conference of Muslim Scholars, 2018, 66.

${ }^{28}$ Muafiah, 69.

${ }^{29}$ Irwan Safarudin Harahap, "Perlindungan Hukum Terhadap Anak Korban Kejahatan Seksual Perspektif Hukum Progresif," Media Hukum Fakultas Hukum Universitas Hukum Tapanuli Selatan, 2016, 41.
} 
tentunya banyak berdampak negatif, terlebih untuk anak perempuan. Pernikahan anak dibawah umur ini telah menjadi sorotan di komunitas internasional dan menjadi isu penting karena adnya kausu pernikahan anak di bawah umur menjadi penghambat tercapainya Sustainable Development Goals yang ditetapkan pada tahun 2015 oleh Majelis Umum PBB. Sementara di Indonesia tentang pernikah anak sudah diatur dalam Undang-Undang Nomor 01 tahun 1974 tentang Perkawinan yang diperbarui menjadi Undang-Undang Nomor 16 tahun 2019 tentang perubahan atas Undang-Undang Nomor 01 tahun 1974 tentang Perkawinan pada Pasal 7, dimana batas usia menikah adalah 19 tahun untuk pria dan wanita. 


\section{DAFTAR RUJUKAN}

Amar, Syahrul. "Perjuangan Gender dalam Kajian Sejarah Wanita Indonesia Pada Abab XIX." Fajar Historia Vol. 1 No. (2017).

Badilag MA RI. "Jalan Panjang Kewenangan Mengawal Hak-Hak Anak", Majalah Peradilan Agama Edisi 9," n.d.

Bandhare, Murlidhar C. The World of Gender Justice. New Delhi: Har-and Publications PVT LTD, 1999.

Hamzani, Achmad Irwan. “Pembagian Peran Suami Isteri dalam Keluarga Islam Indonesia (Analisis Gender Terhadap Inpres No. 1 Tahun 1991 Tentang Kompilasi Hukum Islam)." Sosekhum Universitas Pancasakti Tegal Vol. 6 No. 9 (2010).

Harahap, Irwan Safarudin. "Perlindungan Hukum Terhadap Anak Korban Kejahatan Seksual Perspektif Hukum Progresif." Media Hukum Fakultas Hukum Universitas Hukum Tapanuli Selatan, 2016.

Khotimah, Khusnul. "Diskriminasi Gender Terhadap Perempuan Dalam Sektor Pekerjaan." Studi Gender Dan Anak Yin Yang Pusat Studi Gender STAIN Purwokerto Vol. 14 No. 1 (2009).

Kurniasari. "Peran United Nations Chilren's Fund (UNICEF) Terhadap Penanganan Kasus Pernikahan Anak Dibawah Umur Di India Tahun 2013-2017." Universitas Pembangunan Nasional Veteran Yogyakarta, 2018.

Muafiah, Evi. "Realitas Segregasi Gender Di Pesantren." In Proceedings of Annual Conference of Muslim Scholars, 2018.

"Pedomaan Pelaksanaan Tugas Dan Administrasi Peradilan Agama Buku II." Jakarta, 2014.

Prihatinah, Tri Lisiani. “Tinjauan Filosofis Undang-Undang Nomor 1 Tahun 1974." Dinamika Hukum Vol. 8 No. 2 (2008).

Qibtiyah, Mariyatul. "Faktor Yang Mempengaruhi Perkawinan Muda Perempuan." Biometrika Dan Kependudukan Vol. 3 No. 1 (2014).

Rahmawati, Anita. "Harmoni Dalam Keluarga Perempuan Karir." Palastren STAIN Kudus Jawa Tengah Vol. 8 No. 1 (2015).

Rokhimah, Siti. "Patriarkhisme dan Ketidakadilan Gender." Muwazah Vol. 6 No. 1 (2014).

Rokhmansyah, Alfian. Pengantar Gender dan Feminisme. Yogyakarta: Garudhawaca, 2016.

Sujatmoko, Andrey. Hukum HAM dan Hukum Humaniter. Jakarta: Raja Grafindo Persada, 2015.

“Undang-Undang Nomor 16 Tahun 2019 tentang Perubahan Atas Undang-Undang Nomor 01 Tahun 1974 Tetang Perkawinan," n.d.

Wibowo, Edi. “Peran Ganda Perempuan Dan Kestaraan Gender." Muwazah Vol. 3 No. 1 (2011). 
40 | Indah Fatmawati

ljougs, Volume 1 No. 1 Tahun 2020 